\title{
IDEALISTIC AND REALISTIC TYPOLOGIES OF PEACE
}

\author{
By Lt. Col. Krzysztof Drabik*
}

\begin{abstract}
Multiple perspectives can be brought to bear on the concept of peace: political, cultural, religious, sociological, psychological, or philosophical. Every attempt to describe the concept of peace narrows its meaning to the concrete terms of a particular humanistic or scientific discipline, simultaneously subjectively reducing that term. This status quo raises difficulties related to the epistemological field of peace research. One consequence of these complications is to call into question the name of the field itself. The term "peace research" is strictly descriptive - that is, it describes the area of research, but does not precisely identify its object. In contrast, the names of detailed sciences, like psychology and sociology, which are built upon academic tradition, synthetically set forth their object of research. Questions should be asked concerning the roots of the difficulties in finding an adequate and unequivocal name for the overall field of peace research, one that would simultaneously call attention to the interdisciplinary nature of that research. The problem of identifying a homogeneous domain of study is a result of the complex and multifaceted character of peace research, which is considered supradisciplinary.
\end{abstract}

\section{Introduction}

The following article is an attempt to set forth not just the etymological complexity of the notion of peace, but rather its objective ambiguity. I think that an analysis derived from social philosophy and the philosophy of security constitutes a proper research method, as their characteristic generality seems to be an appropriate way to analyze the subject.

Peace research is carried out from the disciplinary viewpoints of political science, cultural studies, religion, sociology, psychology, and philosophy. Every attempt to describe the notion of peace limits its meaning to the current definition within a specific scientific discipline, thus inducing its objective reduction. Such an approach presents difficulties connected with the epistemological identity and coherence of the field called "peace research," and in effect hampers naming it explicitly. The term "peace research" has a strictly descriptive dimension, but it does not precisely define

* Krzysztof Drabik received his Ph.D. from the Faculty of Philosophy and Sociology at Marie Curie-Skłodowska University in Lublin. Since 2005, he has been a lecturer on the National Security Faculty of the Polish National Defense University in Warsaw. 
its subject matter. The names of traditional academic sciences, such as psychology or sociology, derive from traditions of inquiry that synthetically determine the objective research area of the respective disciplines. What is the origin of our difficulties in finding an adequate and explicit term for the overall field of peace research that would reflect its interdisciplinary character? The problem of identifying a homogeneous area of objective inquiry is a result of the complexity and many-sidedness of peace research, which cannot be subsumed within the boundaries of any traditional discipline. It is difficult to classify the cognitive area of peace science unambiguously, because it includes theoretical foundations and methodologies drawn from many disciplines.

Despite difficulties in classifying the referent for peace research, the search for an adequate term that would represent a form of objective compromise continues. The search for a synthetic term to refer to this field, like in other exact sciences, starts with the etymology of the Greek and Roman tradition. In the literature we can find terms such as irenology, polemology, conflictology (die Konfliktforschung) or securitology. However, none of these terms accurately captures the range of approaches represented by peace research.

Every attempt to explicitly define peace research, regardless of the applied terminology, is ultimately confounded by the impossibility of reducing the subject of study to one specific term. Irenology (from the Greek eirene, for peace), for example, is claimed to be the term that best describes peace research, but it has not been accepted in the scientific world mainly because of the discrepancy between its semantic meaning and the complexity of the cognitive area it covers. There are so many referents for peace, and so many research methods at use within the field, that it is almost impossible to include them in one synthetic term. The analysis of the semantic meaning of the word peace shows a primary difficulty in both the explicit and generalized interpretations of the subject of study in this area. Józef Borgosz emphasized the problem of searching for an adequate term for peace research. In his opinion, irenology has not been accepted as a descriptive label because of the interdisciplinary character of peace research - that is, this one term does not specify both the subject and the character of the study. ${ }^{1}$

\section{Personal and Structural Peace}

It seems that a holistic attempt to capture the subjective area of inquiry of peace research is cognitively valuable, though it is a difficult task. It is widely accepted that peace research (Friedens-Konfliktforschung) as a field adopts a supradisciplinary perspective. From this perspective, a multidimensional categorization of different

J. Borgosz, Drogi i bezdroża filozofii pokoju (Warsaw: Wyd. MON, 1989), 261. 
"peaces" is carried out in accordance with accepted classificatory criteria.

The multidimensional nature of peace, which is already revealed on the semantic level, implies further difficulties in taking a synthetic approach to the subject of study. Generally, intuitive recognition of peace does not cause many problems as long as there is no deep research analysis applied concerning its genesis, characteristics, and the possibilities of dissemination. The way the term is used in scientific papers in various disciplines reflects the research areas of these disciplines, and as a rule is not subject to precise description. Most uses of the term peace in scientific papers are of an a priori character, and silently assume that the reader recognizes its meaning, which may arise from the context but can often result in many interpretative doubts. The literature offers numerous definitions of the term, which only hint toward a generally accepted understanding of the appropriate referent for "peace."

The primary criterion for determining the significative area of peace is a unit and structure. Peace can be discussed as personal (individual) and structural (collective, social, international). Peace in the first sense is a subject for psychological research, described as "peace of mind" or "internal harmony." Personal peace results from a resolution of an inner struggle, which can be exemplified by a moral conflict. ${ }^{2}$ This essay will not deal with this kind of peace, as I want to address more closely the traditional structural understanding of peace, which is a state of relationships in human communities.

\section{Idealistic-Realistic Typology of Peace}

Janusz Świniarski, in his analysis of the issues of safety, pointed out the following types of peace: ${ }^{3}$ perfect, real, and actual. The main criteria for this division are the

2 Maria Ossowska defined a moral conflict as follows: "Talking about a conflict, we can understand it differently. When it happens in the individual's psyche, experiencing a conflict means being in a dilemma. It happens when we face a choice between two values, which we cannot have together at the same time or between two bad possibilities, which cannot be both avoided." An inner conflict is a fight with self, it is a lack of inner harmony and peace. M. Ossowska, Normy moralne - próba systematyzacji (Warsaw: Wyd. PWN, 1985), 159 (author's translation). From his significative perspective, a connection could be drawn to an inner war (inner jihad) deriving from the Islamic tradition. According to Muhammad, inner jihad is more important than outer jihad: "Here we have returned from the lesser jihad - from the war jihad against the supporters of polytheism, (...) to the greater jihad, spiritual jihad, a fight against ourselves...." M. H. Belkhodia, "Guerre et paix l'optique de la tradition musumane," in Les Religions et la guerre (Paris: Editions du Cerf, 1991), 364 (author's translation). Inner peace provides a necessary foundationa for creating outer peace.

3 J. Świniarski, O naturze bezpieczeństwa (Warsaw: Wyd. Ulmak, 1997), 21. 
genesis and perspective of the realization of peace in the world. The hierarchy of the division shows two elements, theological and anthropological. The first is connected with perfect peace, while the latter deals with real and actual peace.

The significative structure of peace in accordance with the this classification is shown in the following diagram:

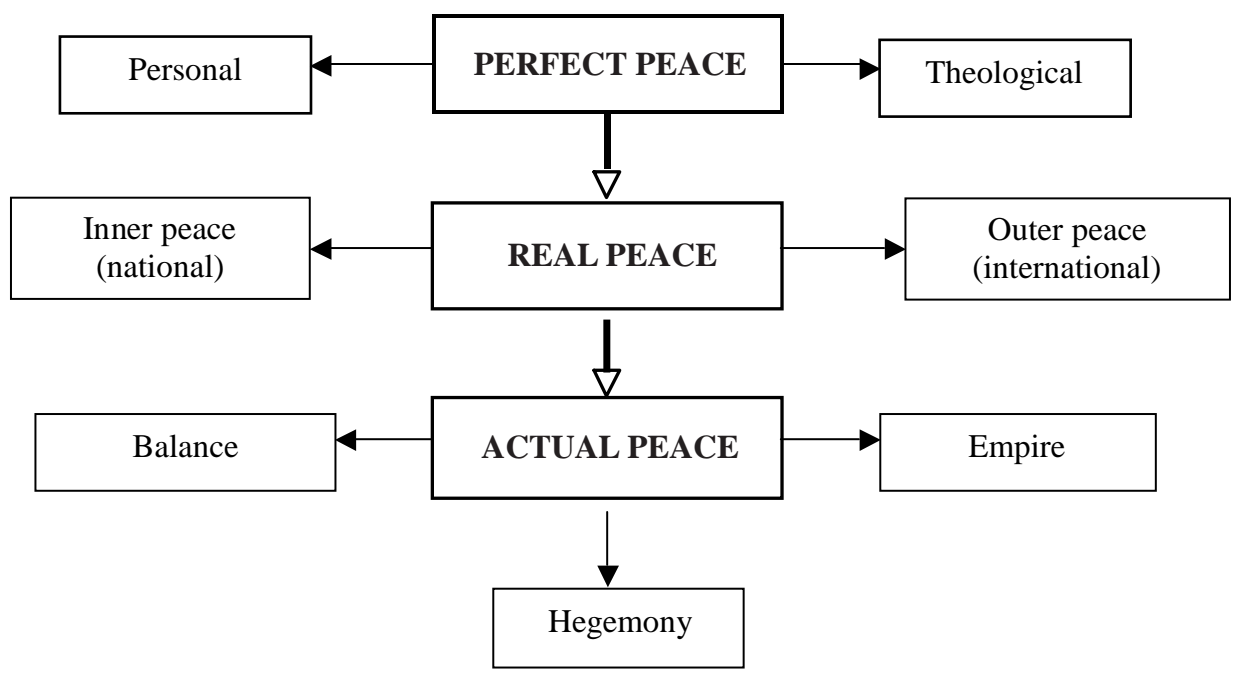

The above diagram shows a hierarchic order of moving from idealism to realism, from theory to practice, and especially from absolute peace to relative peace, the socalled "war-peace."

\section{Perfect Peace}

Etymologically, the notion of "perfect peace" goes beyond the reality of the world, and includes the religious aspects of peace. Only a transcendental being has the power to shape such peace. Idealism as such contradicts the reality of the world, reducing it to the realm of intuition and ideas. Thus, perfect peace goes beyond the arena of human causal power. There is, however, a need to concentrate on the deeper, transcendental aspect of perfect peace. The prospect of shaping such peace evades not just empiricism, but even idealism. It is difficult to find a realization of such peace in the realm of intuition and ideals, which proves that this "perfection" absolutely rules out the cognitive capabilities of man not only, as Immanuel Kant put it, in the unifying power of reason but also in the metaphysical power of mind. Perfect peace goes absolutely beyond human causal power in both the praxeological and especially intentional-notional dimensions. This kind of peace was prophesied by Micah in the 
Old Testament, where it is written that perfect (eternal) peace will come to pass with the advent of God's kingdom on Earth. In the Book of Micah we read: "And he shall judge among many people, and rebuke strong nations afar off; and they shall beat their swords into plowshares, and their spears into pruning hooks: nation shall not lift up a sword against nation, neither shall they learn war any more. But they shall sit every man under his vine and under his fig tree; and none shall make them afraid." This non-empirical and a priori view of peace assumes that the facts of human existence rule out the possibility of shaping eternal peace because hatred, aggression, and lack of trust dominate in the reality of interpersonal and international relations. Besides, human beings in their nature are more egoistic than altruistic.5 However, by comparison with modern times, many authors thought that the militarism of the Old Testament was a result of ignorance as well as of a certain morality and mentality that did not presume the existence of any solutions to conflicts other than war. ${ }^{6}$

Micah 4: 3-4.

5 The first rule of political realism according Hans J. Morgenthau is to assume the determining role of human nature in shaping political relations between countries.

6 Sigmund Freud marked a difference between primeval, primitive communities and developed nations. The first see war as a "natural" way to solve disagreements, while the latter view it as an unethical, despicable action. Hence Freud assumed that "human kind will be for some time preoccupied with wars against underdeveloped or savage nations." Sigmund Freud, "Aktualne uwagi o wojnie i śmierci," in Pisma społeczne (Warsaw: Wydawnictwo KR,1998), 29 (author's translation) . 


\section{Real Peace}

Real peace is the subject of human intentionality, expressed in the form of numerous utopian concepts of the social order. The issue of real peace can be analyzed according to two research streams: the concept of a perfect state, and the concept of international peace. The first research stream concerns ideas of a perfect state whose structure guarantees happiness and protection for its citizens. The latter stream includes idealistic notions of global peace. ${ }^{7}$

Idealized constructions reflect the need to find the best possible social structure aimed at its citizens' happiness and the state's good, which means a primary emphasis on securing internal peace, whose function to help shape international safety. A strong and fair state guaranteed safety for its citizens by securing internal order and possessing adequate military power to protect itself against any potential aggression. Plato was one of the earliest practitioners of the exercise of constructing a perfect state, in his Republic. This creator of the first philosophical system sketched a vision of a perfect state, ensuring happiness for individuals and also guaranteeing their safety. Plato's state was an opposite to conditions of threat, which in the philosopher's opinion contributed to outbursts of military conflict. The state was a model for the global order as a whole and for particular units; it served as a source of justice, and controlled adverse demographic changes, such as overpopulation. The national social order is an optimization of justice, self-sufficiency, and happiness, which can be achieved through the harmonization of three virtues: wisdom, prowess, and moderation. It is important to keep in mind that Plato sought social harmony through the policy of birth control and dividing children into categories, mainly those who may be useful for the state and those who are useless and redundant: "There is a need ...

7 Differences between peace within a country and beyond its borders were emphasized by Plato, who referred to two kind of military conflicts: civil war and war. The most important goal is to establish peace within the country, which directly affects citizens' happiness and the country's stability. Peace beyond the country is not a priority value, especially in relations with barbarians. Plato presented war with non-Hellenic peoples as a natural practice resulting from cultural differences. Therefore the Platonic concept is primarily focused on the basic principle of domestic peace, and the virtue of martial prowess, which is made manifest in the fight with barbarians, strengthens harmony and justice of the social order within the country. Plato made an axiological division between civil wars and outside wars: the first ones endanger peace, the latter are a natural practice of Hellenic civilization. "When Hellenes fight with barbarians and barbarians with Hellenes, we say this is a war and they are enemies by nature. Such hostile relations should be called war. And when Hellenes do this with Hellenes, and by nature they are friends, we say it is Ellada's disease and internal disintegration." Plato, Państwo (Kety: Wyd. Antyk, 2003), 173 (470 D) (author's translation). Thus, in Plato's concept we can distinguish two kinds of war: natural (positive) and unnatural (negative). 
then ... for the best men to entertain relations with the best women most often and the worst with the lowest most seldom, and the offspring of those couples need to be kept and of these not, if the flock is to be first class." ${ }^{\prime}$

The aim of humankind is to live in peace, and the primary exemplification of peaceful harmony is a just state, which is ready for war with an outside enemy. However, war is not an end in itself, but rather a means to peace. Plato's idea of a state is an example of a construction of real peace, which is based on total state control. The laudable intention of prolonging peace and safety clashes here with the mechanistic treatment of human beings as cogs in the state machine. The specific costs of achieving Plato's real peace include objectifying individuals, total collectivization of social life, and unethical behavior by the authorities. The last element became the foundation for the theory of political realism, which Plato presented in Socrates' voice as follows: "It seems that our rulers will often have to use lies and deception for the good of the ruled."

Another example of a construction of real peace expressing a human need for safety is the description offered by Thomas More in his Utopia. More's Utopia is another example of a postulated peaceful social order shaped in opposition to the reality of the sixteenth-century Reformation world in which More lived. Utopians live in peace because their axiology is based on values irrelevant to real social conditions. Gold is not valued as bullion, and to restrain harmful desires it is used for making toilets. In Utopia there is no private property, and citizens constitute one large family, which is strengthened by the lack of any disparities in material wealth. Utopia's harmony and internal peace is highlighted by its full readiness for military action outside the state, although war is viewed as a last resort. For Utopians "war is an atrocity, from which they turn away in disgust and are surprised that a man resorts to it more often than any other species of wild animals. ... Despite this on certain days they practice the art of warfare, both men and women, in order to learn skills in case of war."10

Thomas Hobbes also refers to the idea of real peace expressed through the institution of a state. In his Leviathan, he also addresses the necessity of guaranteeing safety for the citizens of the state, particularly in circumstances where the arena of international relations is rife with instability, and a state of war prevails among all countries (the "war of all against all"). The establishment of the feudal lord's authority suppresses the individual, internal dimension of war: "Leviathan has only become a huge machine, an enormous mechanism which is to secure the temporal and physical existence of those whom it rules and protects." ${ }^{11}$

\footnotetext{
$8 \quad$ Ibid., 161 (459 E).

9 Ibid., (459 D).

10 Thomas More, Utopia (Lublin: Wyd. Daimonion, 1993), 112 (author's translation from the Polish).

11 Thomas Hobbes, Lewiatan (Kraków: PWN, 1954), 47 (author's translation from the Pol-
} 
The concepts of real peace outlined above are intentional reflections on the notion of peace within a state. In all these circumstances, the state directly guarantees every citizen's safety. In opposition to these theories of the perfect state, Immanuel Kant's theory of eternal peace is an example the second stream of idealistic concepts of real peace, that of global peace. In the ancient philosophical tradition we can find elements of the notion of global peace, such as the federalist pacifism outlined by the Sophist philosopher Hippias of Elis. According to this view, the existence of countries and borders constitutes the main reason for wars and conflicts. There is no need to create peaceful social structures within a state if its very existence does not serve the idea of peace in its global sense. Hippias proposed the abolition of state borders in the interest of "a global community," a community of people and nations. ${ }^{12}$

Kant's concept represents a confluence of the currents of domestic and global peace. The existence of states does not preclude peaceful relations between them. A condition of peaceful relations between countries is a process of change in individual countries that gradually introduce the republican system. Only republics, according to Kant, can ensure a stable international peace. The guarantee of peace within a state results from the republican order, whose attribute is individual freedom. Thus every citizen can fulfill themselves through the internal structures of the state- the state enables its citizens to feel safe, and this feeling of safety is a key attribute to a peaceful foreign policy. A republican state is on principle prepared to solve all disagreements in a peaceful way. Kant included the attributes of a state that help prolong the idea of eternal peace in six preparatory and three conclusive articles. From the viewpoint of the possibility of shaping international peace, the second conclusive article is especially important; it states that international relations should be based on the principle of feudalism. The point is to establish an international law that will sanction the state of harmony, peace, and safety among particular republics. ${ }^{13}$

Kant overcomes the cosmopolitan antinomy of Hippias and reconciles the legal validity of a republican state with an idea of the federalization of republican states. In this way, he joins the two currents in his reflection on real peace: the concept of a perfect state with a structure that ensures the happiness and safety of its citizens, and the idealistic concept of global and eternal peace. Consequently, he also eliminates the Hobbesian state of war among all states from the arena of international relations.

Many of the concepts contained under the category of real peace can be placed under the heading of "moderate idealism," as opposed to the absolute idealism represented by the Old Testament pattern of perfect peace. Real peace is a construction of

ish).

12 J. Borgosz, Drogi i bezdroża, 25.

13 I. Kant, Wieczny pokój, thum. J. Mondschein (Toruń: Wyd. Adam Marszałek, 1992), 23-27 (author's translation from the Polish). 
a human mind based on actual political relations, which simply need to be suitably modified and arranged. The process of "real idealization" of peace, on the other hand leads (according to the criteria set forth above) to some abstract change of the current situation of a state and international relations, which in accordance with its creator's concept would serve to ensure local and global peace. Real peace is a reflection of the richness of a notional configuration, and remains so in practice. All attempts to go from real peace to actual peace have failed thus far, but going the other way remains a possibility, because it concerns an intentional sphere.

\section{Actual Peace}

Actual peace is currently a subject of descriptive analysis that is often reduced to the level of political discourse. It involves specific descriptions of real occurrences and events in the arena of international relations. Actual peace directly reflects the complexity in the dialectical world of social, natural, and technical entities. J. Świniarski, in his description of the Old Testament fate of the Israelites, emphasized the etymological specificity of peace. Israelites "waiting for real peace first looked after actual peace while flexibly adapting and drawing on thousand-year traditions in which man-made peace had never been lasting and binding enough to prevent a new war."'14

One key attribute of actual peace is its impermanence. Such peace is not an object of intention or a work of a transcendental being, but a result of specific actions determined by characteristics of human nature, which (according to many thinkers of the Machiavelli or Hobbes school) is filled with egoism and aggression. Actual peace is an authentic "verifier" of all utopian concepts of real peace. This is a specific clash of theory and practice, in which practice remains the only criterion defining the specificity of relations between individuals and states. In this kind of peace, the theory includes descriptions of past and present events, revealing the militaristic complexity of human relations. Thus the point is not to plan and idealize prospective concepts of peace, but to describe real events and, on their basis, form theoretical pictures of reality, in which war is an inherent attribute of the world of social entities.

The problem of actual peace is the area of research within international relations that is most often identified with the current of political realism. Political realism is the most adequate reflection of the essence of actual peace, which is a kind of compromise, a balance between what is constructive (peace) and destructive (war). Real peace and perfect peace are far from this ontological compromise.

Actual peace is an extra-intentional, practical agreement, including realism in political relations. It includes certain formulations of "war-peace," "militaristic

14 J. Świniarski, O naturze bezpieczeństwa, 23 (author's translation). 
pacifism," or "an armed peace." The state of peace, which is a reflection of an ontological balance, is a dualism between good and evil, peace and war, and thus it directly reflects a practical, military-pacifistic realism in international relations. The difference between the abstractness of perfect peace and the concreteness of actual peace was aptly pointed out by the Prussian militarist Helmuth von Moltke, who stated that the idea of eternal peace can only be the substance of daydreams, while the reality of a war is the human reality: "Eternal peace is a dream-not even a beautiful one - and war is an integral part of the God-given world order. During a war there come to the fore the noblest human virtues: courage and selflessness, dutifulness and self-sacrifice, which can even put at stake one's own life. Without a war the world would be stuck in the mud of materialism." 15

The above opinion is symptomatic of a difficulty connected with the etymological meaning of actual peace. The problem is to explicitly qualify the military-pacifistic agreement. In this context, is it even justified to use the term peace? An example of this challenge is a proper definition of the state of "cold war," referring to the bipolar political system created after World War II. A question arises: in this particular case, are we dealing with a state of war or a state of peace? This situation cannot be explicitly defined within the category of a classical armed conflict, nor within the category of peace, if it is understood as a state characterized by the absence of threats. ${ }^{16}$

It can be assumed that the specificity of actual peace comes down to the state of so-called "war-peace" that is used in describing militaristic realities in international relations. Thomas Hobbes did not directly speak about peace as such, but rather about the state of war, which is not the same as a direct armed clash. The nature of war that Hobbes emphasizes lies not in a real struggle, but in the "visible readiness for this all the time when it is not certain that it is otherwise. All other time is time of peace

15 H. von Moltke, za thum. T. J. Dehnel przekładu A. J. Toynbee „Wojna i cywilizacja”, p. 24 (author's translation). [Author: please provide full citation information, including publisher.]

16 Raymond Aron analyzed the semantic specificity of "cold war," defining it in the category of warlike peace. The author negatively answers his question: "Does a currently popular notion of cold war undermine the distinction between war and peace?" "Cold war" is a specific kind of peace consisting of peace based on fear and the unique historical and ideological characteristics of the system. These specific features show the direction of political tactics used by the world powers, which can be the first phase in the process of creating a more lasting peace, although containing a permanent element of distrust. This ultimate peace would be a result of outdating the first phase of peace based on fear and the accompanying arms race. As Aron emphasizes, "Mankind has not gotten used to the new world yet ... and cannot function without a thermonuclear threat. ... It is also uncertain if in the long run the strategic usefulness of such a threat can be reconciled with not fulfilling it." Raymond Aron, Pokój i wojna między narodami (Warsaw: Wyd. Centrum im. Adama Smitha, 1995), 212-13 (author's translation from the Polish). 
then." ${ }^{17}$ The above interpretation, when applied to the "war-peace" reality, significantly reduces the period of time that can be described as peace.

Depending on which terminological convention is applied, the modern world of international political relations can be defined either within the category of actual peace or a state of war. This ambiguity directly results from the typology of peace included in the general category of actual peace. Raymond Aron distinguished three types of peace reflecting realism in international relations 18: balance, hegemony, and empire.

The criteria used to determine these classifications are the strength (power) of the political units. A relational arrangement of international relations is based on a differentiated configuration of powers. It is focused on establishing a specific hierarchy of advantage of some over others on a spectrum from balance through hegemony (moderate domination) to the state of empire (characterized by a huge disproportion of power, including the abolition of the autonomy of weaker political units).

Aron's typology is a classical reflection of political realism implying the primary role of power in international relations. Actual peace in the many forms of realism has found its semantically proper place. ${ }^{19}$ The precursor of the realist approach to international relations, Hans J. Morgenthau, formulated six rules of political realism: ${ }^{20}$

1. A social structure and its politics are determined by objective and universal laws, regardless of human will, which arise from human nature.

2. The national interest is a central criterion defining trends in politics. The realization of this interest is based on power.

3. The national interest is an objective category.

17 Hobbes, Lewiatan, 110.

18 R. Aron, Pokój i wojna, 198.

19 Political realism evolved towards neorealism and structural realism. Kenneth Waltz is the main proponent of neorealism. He thinks that it is impossible to explain phenomena in the arena of international relations by means of naturalistic human predispositions. Waltz states that the theory of international relations should be of a systemic nature. Barry $\mathrm{Bu}-$ zan, who is a representative of structural realism, underlines a difference between neorealism and structural realism. The latter notion defines an international system as a functional structure. The structural approach describes not only the character of international relations, but also analyzes subjects of interactions within their structural complexity. Thus individual structures influence the quality of the entire international system. See Kenneth Waltz, Theory of International Politics (New York: McGraw-Hill, 1979); Barry Buzan, Charles Jones, \& Richard Little, The Logic of Anarchy: Neorealism to Structural Realism (New York: Columbia University Press, 1993).

20 Hans J. Morgenthau, Politics Among Nations: The Struggle for Power and Peace (New York: Alfred A. Knopf, 1978), 4-15. 
4. Politics in general is founded on moral criteria, but assumes their transcendence.

5. In the arena of international relations "political relativism" is dominant. No values or interests can be considered in the universal category.

6. Political realism is an autonomous concept in evaluating international relations.

Morgenthau's realism derives from the application of individual naturalism to the plane of political relations. It is a continuation and extension of Machiavelli and Hobbes's pejorative assessments of human predispositions as more egoistic than altruistic. The dialectics of egoistic human nature and the particular demands of the national interest form the plane of political realism, in which actual peace becomes an element of describing the complex practice of international relations at wide variance from the intentionally and theologically conditioned peaces of a "higher order."

\section{Conclusion}

It must be stated that perfect peace and real peace belong to a sphere which is largely alienated from the realm of social reality and goes beyond the area of activity of the principle of causality in the world of social entities. Actual peace, which is a description of actual social, cultural, and political phenomena, and also forms their synthesis in the process of political planning, is placed in the circle of human egoism, national interests, and international systems and structures.

Political realism (and consequently the concept of actual peace) assumes that history is a sequence of causes and effects, whose course can only be analyzed intellectually instead of notionally. Moreover, the difference between perfect (real) peace and actual peace can be compared to the relationship between theory and practice. The specificity of actual and real peace is determined by the creative role of theory, which aspires to change practice. Actual peace reflects the reverse direction: practice creates theory. Knowledge of the social reality is collected on the basis of research within the context of this reality. The characteristic dualism of an intentional man and a pragmatic man can be highlighted here - it is the antagonism between imagination and naturalistic reality, and in the most general sense between theory and practice. This theory is that of the egoistic human nature, and the practice is the necessity of existence in a community, for which we should give up part of our natural rights. The goal, then - keeping in mind the sense of actual peace - is to minimize the antagonism between the private interest and the public (national) interest, and also between interests in the international arena.

In general, this discussion is concerned with the influence of theory on changes of practice in social life. In order to make the influence the least "utopian," and to realize real peace, there must be a constitutive change in the human nature that would 
reflect a tendency toward more constructive (peaceful) actions rather than destructive (warlike) ones. Jürgen Habermas emphasizes that the point is to examine the susceptibility to change within human nature with an eye toward avoiding victimization and suffering within the current social reality. The problem of the relationship between theory and practice as outlined by Habermas provides an accurate summary of my deliberations, and perhaps an adequate solution to the problems embracing the "tragedy" of human life in the fetters of actual peace. "The attempts of emancipation," as Habermas claims, "which are also attempts to realize the utopian content of the cultural tradition, can be interpreted as a practical necessity, pointing at conflicts caused by the system and avoidable victimization and sufferings. ... They test the limitations of the changeability of human nature, first of all the historically inconsistent structure of desires, the boundaries of which we have no theoretical knowledge. ${ }^{21}$

21 Jürgen Habermas, Teoria i praktyka (Warsaw: Państwowy Instytut wydawniczy, 1983), 62 (author's translation from the Polish). 


\section{Bibliography}

Aron, Raymond. Pokój i wojna między narodami. Warsaw: Wyd. Centrum im. Adama Smitha, 1995.

Belkhodia, M. H.. "Guerre et paix l'optique de la tradition musumane." In Les Religions et la guerre, 364. Paris: Editions du Cerf, 1991.

Borgosz, J.. Drogi i bezdroża filozofii pokoju. Warsaw: Wyd. MON, 1989.

Buzan, Barry, Charles Jones, and Richard Little. The Logic of Anarchy: Neorealism to Structural Realism. New York: Columbia University Press, 1993.

Freud, Sigmund. "Aktualne uwagi o wojnie i śmierci." In Pisma społeczne, 29. Warsaw: Wydawnictwo KR, 1998.

Habermas, Jürgen. Teoria $i$ praktyka. Warsaw: Państwowy Instytut wydawniczy, 1983

Hobbes, Thomas. Lewiatan. Kraków: PWN, 1954.

Kant, I.. Wieczny pokój. Toruń: Wyd. Adam Marszałek, 1992.

More, Thomas. Utopia. Lublin: Wyd. Daimonion, 1993.

Morgenthau, Hans J.. Politics Among Nations: The Struggle for Power and Peace. 6th, brief edition. Boston: McGraw-Hill, 1993.

O naturze bezpieczeństwa. Warsaw: Wyd. Ulmak, 1997.

Ossowska, M.. Normy moralne - próba systematyzacji. Warsaw: Wyd. PWN, 1985.

Państwo. Kety: Wyd. Antyk, 2003.

Waltz, Kenneth N.. Theory of International Politics. Reading, MA: AddisonWesley, 1979. 